\title{
Raised serum IgG and IgA antibodies to mycobacterial antigens in rheumatoid arthritis
}

G TSOULFA, ${ }^{1}$ G A W ROOK ${ }^{1}$ J D A VAN-EMBDEN, D B YOUNG,
A MEHLERT, ${ }_{3}^{2}$ D A ISENBERG, ${ }^{2}$ F C HAY, ${ }^{1}$ AND P M LYDYARD

From the ${ }^{1}$ University College and Middlesex School of Medicine, London; the ${ }^{2}$ National Institute of Public $\vec{\odot}$ Health and Environmental Hygiene, Bilthoven, Netherlands; and the ${ }^{3}$ Royal Postgraduate Medical School, $\overrightarrow{\vec{\omega}}$ London

SUMMARY Autoantigens cross reactive with mycobacteria are implicated in the pathogenesis of adjuvant arthritis in the rat, and there are reports of changes in the immune response to mycobacteria in human rheumatoid arthritis (RA). We have therefore examined the $\operatorname{IgM}, \operatorname{IgG}_{0}^{\infty}$ and IgA antibody levels to crude mycobacterial antigens and to two recombinant mycobacteriaP heat shock/stress proteins $(65 \mathrm{kD}$ and $71 \mathrm{kD})$ in sera from patients with RA, systemic lupus erythematosus (SLE), and Crohn's disease, and from healthy controls. IgA binding to the crude⿻ mycobacterial antigens was significantly raised in RA sera, though IgG and IgM binding tendect to be lower than in controls. Both IgA and IgG binding to the heat shock proteins were significantly raised in the RA sera. Smaller significant rises in both classes were seen in sera frogne patients with SLE, and in the IgA class only to the $65 \mathrm{kD}$ protein in Crohn's disease. The rises 910 IgG and IgA antibodies to the $65 \mathrm{kD}$ protein in RA were significantly higher than in the other diseases, however. It is interesting that this protein is the one responsible for adjuvant arthritis. $\mathrm{T}$ ह the rat.

Key words: antibodies to heat shock proteins, antibodies to stress proteins.

Rheumatoid arthritis (RA) is believed to be an immunological disease, possibly autoimmune, of unknown aetiology. Adjuvant arthritis, which can be induced in rats by immunisation with mycobacteria in oil, is considered by some investigators to be a model of RA. This disease can be transferred to susceptible rats by $\mathrm{T}$ cell clones specific for Mycobacterium tuberculosis. ${ }^{1-4}$ These arthritogenic clones were found to recognise an acetone precipitable fraction of $M$ tuberculosis. Interestingly, patients with RA were also reported to have raised $T$ cell responses to an acetone precipitable fraction. ${ }^{5}$ This, however, has recently been challenged by the observations that the $\mathrm{T}$ cell responses to an $M$ tuberculosis antigen in patients with RA are DR4 linked and not associated with RA. ${ }^{6}$ More recently van Eden and colleagues have shown that the arthritogenic rat $T$ cell clones recognise a $65 \mathrm{kD}$ protein, which is a component of the acetone

Accepted for publication 15 June 1988.

Correspondence to Dr P M Lydyard, Department of Immunology, Arthur Stanley House, The Middlesex Hospital Medical School, 40-50 Tottenham Street, London W1P 9PG. precipitable fraction preparation. ${ }^{7}$ Evidence that the rat model may indeed be relevant to the human: condition is accumulating. Firstly, an association was detected between skin test responsiveness to $\frac{0}{-}$ tuberculin and DR4 in patients with leprosy, ${ }^{8}$ and 3 . more recently in RA. ${ }^{9}$ Secondly, antibody levels too crude mycobacterial sonicates in sera from patients with RA living in Kuwait (a mycobacterium rich environment) showed significant correlations with HLA-DR haplotypes known to be relevant to susceptibility to RA. ${ }^{10}$

The present study examines the possible associations of antibody levels to mycobacteria, and in N particular to the $65 \mathrm{kD}$ antigen, implicated in then adjuvant athritis model, in patients with RA living ${ }^{\omega}$ in the UK. It has been found that although patients with RA only showed raised IgA antibodies to crude? mycobacterial antigens, IgG as well as IgA antibody levels were raised to the $65 \mathrm{kD}$ and $71 \mathrm{kD}$ antigens.

Patients and methods

SOURCE OF SERUM SAMPLES

This study was carried out on 85 patients with RA, 
as defined by the American Rheumatism Association criteria, attending the outpatient clinic of the Bloomsbury rheumatology unit. Sixty three were female and 22 male, mean age 55 years (range 27-78), duration of disease ranged from two to 20 years, disease activity was based on $\mathrm{C}$ reactive protein levels (Abbot Laboratories kit). They were HLA-DR tissue typed.

Eighteen patients with systemic lupus erythematosus (SLE) attending the above clinic were studied as a control disease as SLE is also a non-organ specific autoimmune disease. Seventeen were female and one male, mean age 42 years (range $30-68)$.

Twenty one patients with Crohn's disease were also included in the study as a non-autoimmune disease group. Ten were female and 11 male, mean age 36 years (range 18-74).

Forty five healthy laboratory staff were studied as a control group. Twenty seven were female and 18 male, mean age 35 years (range 24-63).

\section{SOURCE OF ANTIGENS}

A water extract of $M$ tuberculosis $\mathrm{H}_{37} \mathrm{Ra}$ (Difco) was prepared as follows. Heat killed, desiccated $M$ tuberculosis were ground with a homogeniser, suspended in double distilled water at $1 \mathrm{mg} / \mathrm{ml}$, stirred for eight hours at $4^{\circ} \mathrm{C}$, centrifuged for 30 minutes at $15000 \mathrm{~g}$, and the supernatant was lyophilised. This antigen is referred to as WE. Sonicates of fresh bacilli from $M$ tuberculosis (TB) and $M$ vaccae (VAC) were also used. ${ }^{11}$ The recombinant forms of the $65 \mathrm{kD}$ protein of $M$ bovis $\mathrm{BCG}^{12}$ and the $71 \mathrm{kD}$ protein of $M$ tuberculosis (Mehlert and Young, in preparation) were also used. These antigens are referred to as $65 \mathrm{kD}$ and $71 \mathrm{kD}$ respectively.

\section{ENZYME LINKED IMMUNOSORBENT ASSAY (E L ISA )}

The antigens were coated at $10 \mu \mathrm{g} / \mathrm{ml}$ for WE, TB, and VAC and at $1 \mu \mathrm{g} / \mathrm{ml}$ for $65 \mathrm{kD}$ and $71 \mathrm{kD}$ in carbonate buffer $(0.05 \mathrm{M}, \mathrm{pH} \mathrm{9.6)}$ onto immunoplates (Nunc) and incubated overnight at $4^{\circ} \mathrm{C}$. Excess antigen was washed off with phosphate buffered saline $(0.1 \mathrm{M}, \mathrm{pH} 7.4)$ containing $0.05 \%$ Tween 20 (PBS/T). The test sera were plated in doubling dilutions from $1 / 50$ to $1 / 400$ in $\mathrm{PBS} / \mathrm{T}$ in duplicate and incubated for two hours at room temperature. After further washes with PBS/T the affinity purified $F\left(a^{\prime}\right)_{2}$ fragments of horseradish peroxidase conjugated human antibodies (Sigma) were added at $1 / 1000$ dilution in PBS/T and incubated overnight at $4^{\circ} \mathrm{C}$. The washing process was repeated, and $0.5 \mathrm{mg} / \mathrm{ml}$ of $2,2^{\prime}$-azinobis(3-ethylbenzthiazoline sulphonic acid) (Sigma) in citrate phosphate buffer $(0.1 \mathrm{M}, \mathrm{pH} 4.1)$ with 0.35 $\mu \mathrm{l} / \mathrm{ml} \mathrm{H}_{2} \mathrm{O}_{2}$ vol $20(6 \%$ w/v) was added. After approximately 30 minutes the reaction was stopped with $96 \mathrm{mg} / \mathrm{ml}$ of sodium fluoride (Sigma) in double distilled water, and the absorbance was measured at $650 \mathrm{~nm}$ with a Titertek multiscan ELISA reader (Flow). Throughout the assay the volume of reagents added per well at each step was $100 \mu l$, each wash step was repeated three times with three minutes' incubation between washes at room temperature, and for each individual assay the same positive and negative controls were used.

\section{DATA ANALYSIS}

The values of optical density (OD) ratio were calculated as $\mathrm{OD}_{650}$ of test/OD $\mathrm{OD}_{650}$ of positive serum control in each plate. The serum dilutions used for the calculations were those within the linear phase of the antibody binding curve and were $1 / 100$ dilution for the IgA ELISA of $65 \mathrm{kD}$ antigen and $1 / 200$ for all the other assays. As the mean age and sex of the individuals for the four groups studied were not the same the data were analysed for evidence that the age or sex influenced the antibody levels. The data were also analysed with respect to activity and duration of the disease.

\section{H L A - D R TYPING}

The HLA typing was carried out by The London Hospital, and the frequencies of DR haplotypes in the 85 patients with RA studied were DR1:15, DR2:13, DR3:19, DR4:47, DR5:10, DR6:15, DR7:8, DR8:1, DR9:1, DR10:1, and DR11:1. The data were examined for association between HLADR haplotypes (for which not less than five individuals were available) and antibody levels.

STATISTICAL ANALYSIS

The Mann-Whitney $U$ two tailed test was used to compare the antibody levels in the control and experimental groups. The same test was also used to compare antibody levels of patients with RA in association with HLA-DR haplotypes. The Spearman rank correlation coefficient was used to compare antibody levels of the same group of individuals to different antigens as well as to look for correlation between raised antibody levels and sex, age, disease activity, and duration of the disease. Statistical analysis was carried out using the STSC STATGRAPHICS software package.

\section{Results}

INCREASED IgA ANTIBODY LEVELS TO CRUDE MYCOBACTERIAL ANTIGENS IN RA Patients with $R A$ were found to have raised IgA serum antibody levels to the WE $(p<0 \cdot 01)$, TB 
$(p<0.0001)$, and VAC $(p<0.0001)$ antigens in comparison with healthy controls. Serum samples from $19 / 64,19 / 64$, and $29 / 64$ patients with RA showed IgA levels more than 2SD above those of the healthy control group levels to WE, TB, and VAC respectively. In addition, the IgG and IgM antibody․ㅡ․ levels to the same antigens were lower in RA than in controls (Fig. 1). Serum samples from patients with SLE and Crohn's disease were not tested against the crude antigens.
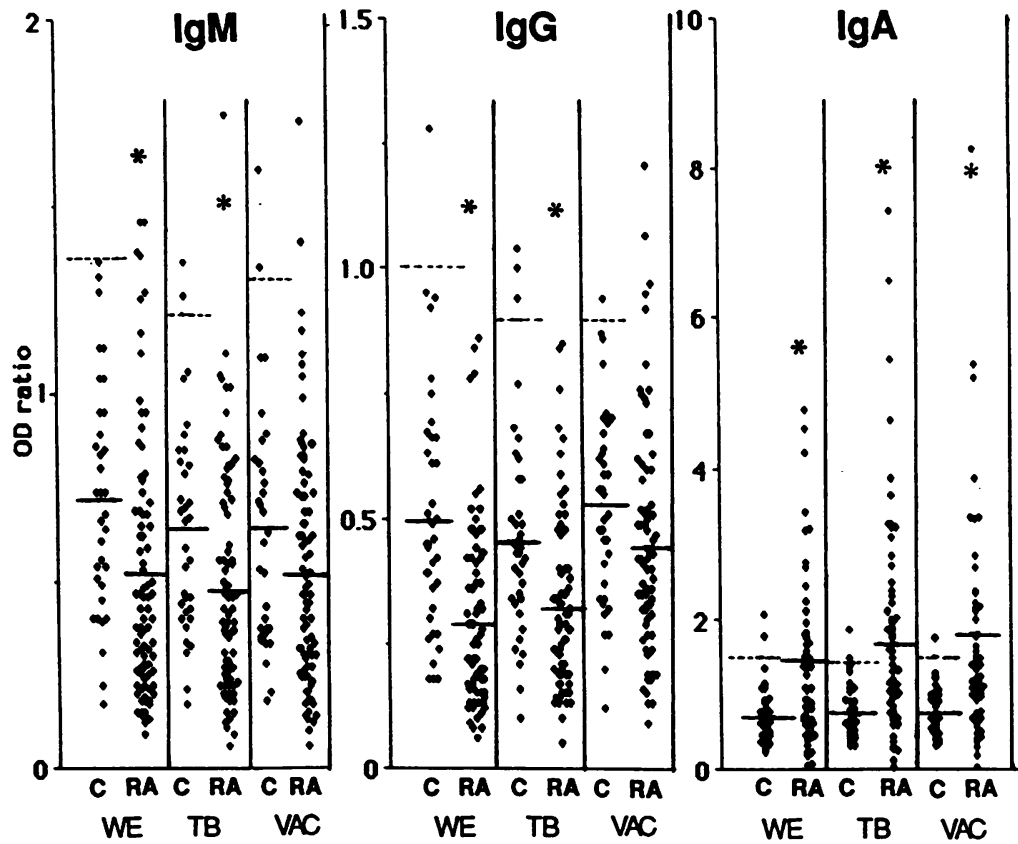

Fig. 1 Antibody levels to WE, $T B$, and $V A C$ antigens in healthy controls and patients with $R A$. The $e_{\infty}$ antibody levels are expressed as $O D$ ratios for each group $(O D$ ratio $=O D$ of test $/ O D$ of control positive serum in each plate). Horizontal lines represent the mean $O D$ ratio for each group and the dotted lines define $2 S D$ of the control mean. ${ }^{*} p<0.01$. $O D=$ optical density; $C=$ control; $R A=$ rheumatoid arthritis; $W E=a$ water extract of M tuberculosis; $\Omega \overrightarrow{0}$ $T B=$ sonicates of $M$ tuberculosisio $V A C=$ sonicates of $M$ vaccae.
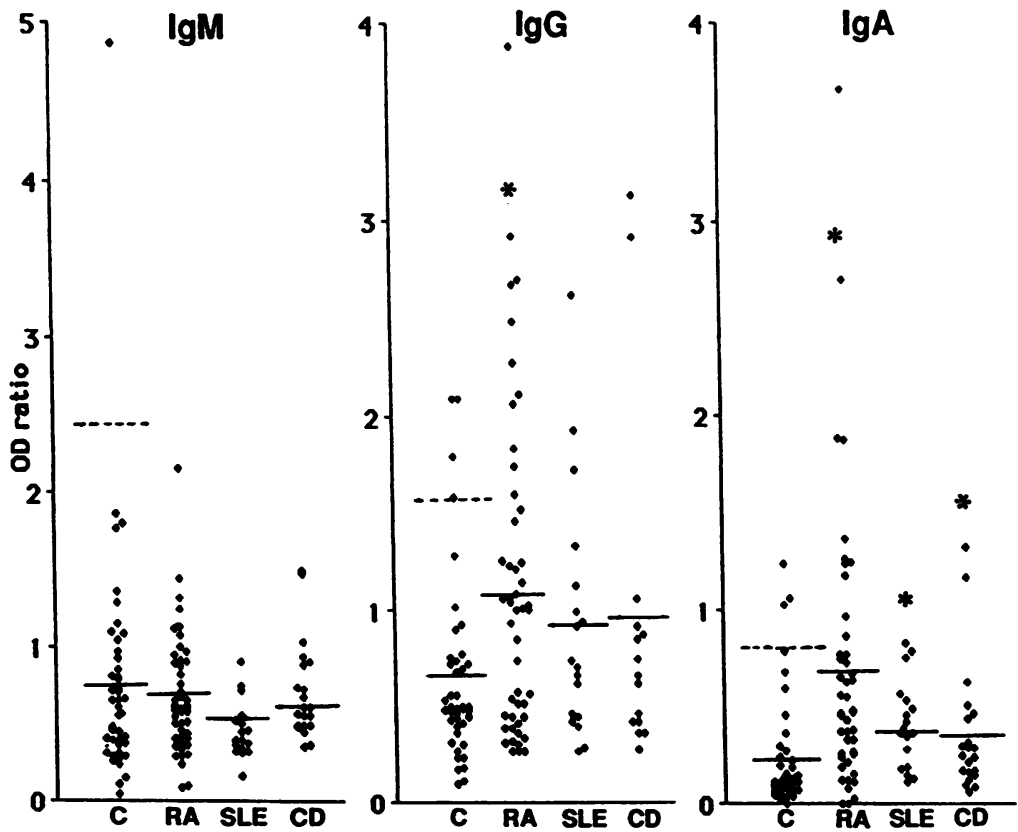

Fig. 2 Comparison of the antibody levels to the $65 k D$ protein? in healthy controls $(C)$, and in patients with rheumatoid arthritis (RA), systemic lupus erythematosus (SLE), and Crohn's disease $(C D)$. Data presented as in Fig. $1 .^{*} p<0 \cdot 01$.

\section{윽}

을. 
INCREASED IgA AND IgG ANTIBODY LEVELS TO THE $65 \mathrm{kD}$ AND $71 \mathrm{kD}$

MYCOBACTERIAL ANTIGENS IN RA

When defined mycobacterial antigens were used the differences in antibody levels in RA and controls were not confined to the IgA class only $(p<0 \cdot 0001)$. Patients with RA also showed raised IgG antibody levels to both antigens when compared with the controls $(p<0.01)$, while their IgM levels were lower (but not significantly) to both $65 \mathrm{kD}$ and $71 \mathrm{kD}$ antigens (Figs 2 and 3). Serum samples from 11/45 and 9/19 patients with RA showed IgA levels to the $65 \mathrm{kD}$ and $71 \mathrm{kD}$ antigens respectively which were more than 2SD above those of the healthy control mean. Also, 10/42 (to the $65 \mathrm{kD}$ ) and 7/39 (to the $71 \mathrm{kD}$ ) RA sera showed raised IgG levels more than $2 \mathrm{SD}$ above those of the control values.

ANTIBODY LEVELS TO THE $65 \mathrm{kD}$ AND $71 \mathrm{kD}$ MYCOBACTERIAL ANTIGENS IN PATIENTS WITH SLE AND CROHN'S DISEASE

Patients with SLE were also found to have raised IgG $(\mathrm{p}<0.001)$ and $\operatorname{IgA}(\mathrm{p}<0.001)$ antibody levels to both antigens, but their IgM levels were not significantly different from the control levels. Although serum IgG levels were raised in SLE to the $65 \mathrm{kD}$ protein, the quantity of antibodies was lower than that seen in sera from patients with RA (Figs 2 and 3). Only 3/18 sera had IgG levels more than 2SD above those of the controls to the $65 \mathrm{kD}$ and $4 / 18$ to the $71 \mathrm{kD}$ antigens. With regard to $\operatorname{IgA}$ levels, only $1 / 18$ sera was more than $2 S D$ above those of the control to the $65 \mathrm{kD}$, while $10 / 18$ sera were higher to the $71 \mathrm{kD}$ protein.

Patients with Crohn's disease, on the other hand, were also found to have significantly raised $\operatorname{IgA}$ antibody levels to the $65 \mathrm{kD}$ antigen $(\mathrm{p}<0.001)$ but again not to the same degree as the RA group (Fig. 2). Only $2 / 21$ sera for the $65 \mathrm{kD}$ antigen had a significantly higher IgA level than the control group.

LACK OF RELATION BETWEEN RAISED

ANTIBODY LEVELS AND AGE, SEX, DURATION, AND DISEASE ACTIVITY

Serum samples of patients with RA with significantly higher IgG and IgA antibody levels were compared with RA sera with antibody levels equal to control levels. No correlation was found between antibody levels and age, sex, disease activity, and disease duration. Similarly, the few patients with SLE and Crohn's disease whose levels were more than 2SD above the control mean did not differ clinically from those with normal values.

ANTIMYCOBACTERIAL RESPONSES AND DR H A P L O T Y PE

The data on mycobacterial responses were examined for associations between antibody levels and HLA-DR haplotypes as other investigators have suggested such associations. Our data showed no

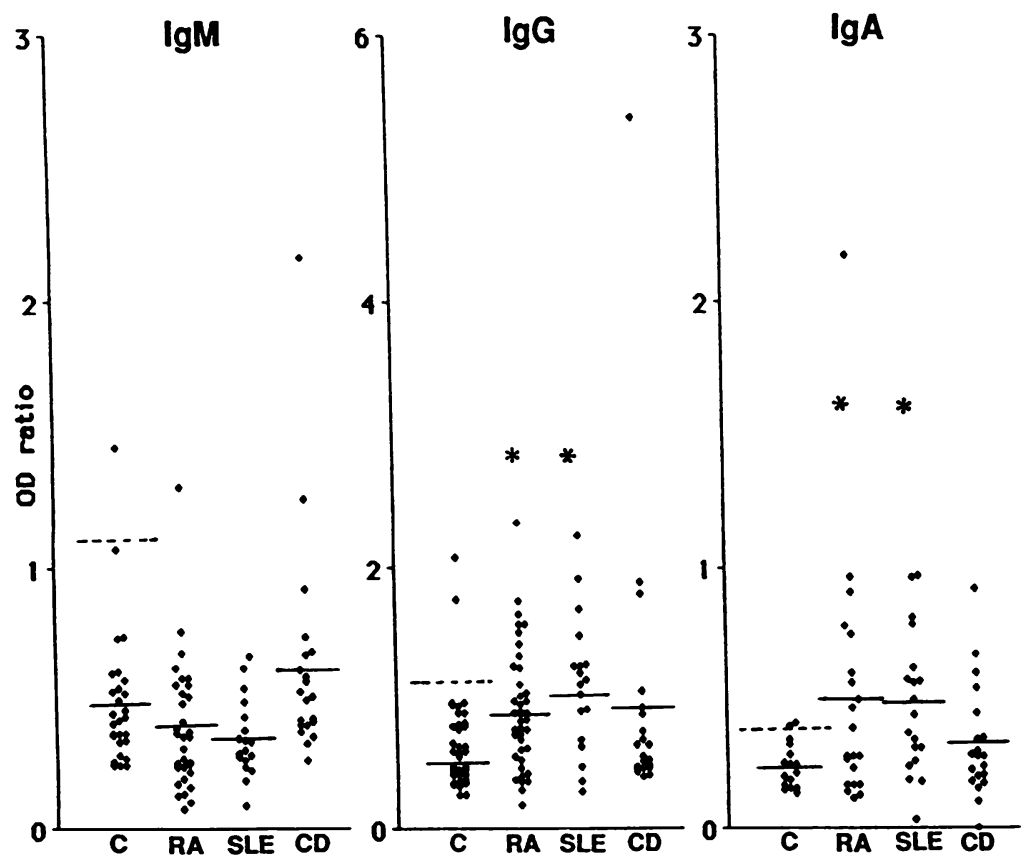

Fig. 3 Comparison of antibody levels to the $71 \mathrm{kD}$ protein in healthy controls $(C)$, and in patients with rheumatoid arthritis (RA), systemic lupus erythematosus (SLE), and Crohn's disease $(C D)$. Data presented as in Fig. $1 .{ }^{*} p<0.01$. 
association with the DR haplotypes shown to be relevant to RA, such as DR4, DR2, and DR7. Although DR1 patients with RA showed higher IgA antibodies to the WE $(p<0.06)$, TB $(p<0.05)$, and VAC $(p<0.02)$ antigens than non-DR1 individuals, these $p$ values do not remain significant when corrected for the number of comparisons made.

\section{Discussion}

This study has shown that patients with RA have significantly raised antibody levels of the IgA class to the crude mycobacterial antigens WE, TB, and VAC. Our data are consistent with a recent study in Kuwait using TB, VAC, and five similar preparations from other species, where there was a tendency towards raised IgA antibody levels in RA sera, though significance was only reached with $M$ nonchromogenicum. All antibody and skin test responses to mycobacteria are high in Kuwait, however, as the environment is rich in mycobacteria. ${ }^{10}$

To obtain more information about the specificity of antibodies to the mycobacteria in the RA sera we examined the levels of the different classes of antibodies to the recombinant $65 \mathrm{kD}$ and $71 \mathrm{kD}$ proteins. Both $\mathrm{IgG}$ and $\mathrm{IgA}$ levels were increased to these 'clean' antigens. The fact that these proteins show no homology with each other indicates that antibodies to at least two major mycobacterial antigens are raised in these patients with RA.

Raised levels to one recombinant protein did not correlate with the antibody levels to the other protein. In fact, analysis of 10 individual patients' sera with higher levels of IgG antibodies to the 71 $\mathrm{kD}$ protein than control sera $(\mathrm{OD}$ ratio $>$ mean $\mathrm{OD}$ ratio $+2 \mathrm{SD}$ ) showed that two sera were also high for the $65 \mathrm{kD}$ protein, the other eight being low for this antigen. Furthermore, some sera with high IgA levels to the $71 \mathrm{kD}$ protein were lower for the $65 \mathrm{kD}$ protein. These observations, together with the findings of lower (but not significant) IgM levels in patients with RA to all mycobacterial antigens tested, argue against polyclonal activation as a source of raised antibodies. Moreover, it is interesting that in Kuwait, where responsiveness to mycobacteria is very high, this tendency for IgM binding to mycobacteria to be low in RA was significantly correlated with DR7, a haplotype known to be protective in RA. ${ }^{10}$

No significant differences were seen in duration and activity of the disease, sex, or age of the patients with respect to antibody levels. This indicates that although raised levels of antibodies are found in these patients with RA, a relation with the disease itself is not yet clear. In this regard we analysed the relation with $\mathrm{DR}$ to determine whether the raised $\underline{ }$. levels could be correlated with known DR haplo-? types previously shown to be related to RA-for $\overrightarrow{\vec{F}}$ example, DR4. ${ }^{13-15}$ No association was found be $-\frac{\overrightarrow{7}}{\frac{0}{2}}$ tween antibody levels and DR4. This result appears응 to be different from data on $\mathrm{T}$ cell responses to $\overline{\bar{m}}$ mycobacteria, which have been correlated with DR4 expression in RA and healthy individuals, ${ }^{6}$ and may be important in relation to the pathogenesis in DR4 ${ }^{\infty}$ individuals. A parallel study in Kuwait with the $\vec{\odot}$ same antigen preparations has shown comparable $\vec{\overrightarrow{ }}$ results with regard to raised antibody levels to the $65{ }_{\sigma}^{\omega}$ $\mathrm{kD}$ protein in RA and lack of meaningful DR@ correlation (Bahr et al, unpublished data).

It is interesting that IgG and $\operatorname{IgA}$ antibody levels $\stackrel{\overrightarrow{0}}{\overrightarrow{0}}$ were raised to both the $65 \mathrm{kD}$ and $71 \mathrm{kD}$ proteins in? patients with SLE, suggesting that the increase of $\vec{\infty}$ antibodies in itself is not disease specific. IgG and IgA antibodies to the $65 \mathrm{kD}$ protein in SLE and $\operatorname{IgA} \stackrel{\circ}{-}$ in Crohn's disease were lower than in patients with $\vec{T}$ RA, whereas antibodies in SLE sera to the $71 \mathrm{kD} \stackrel{\mathbb{O}}{\circ}$ protein were raised but not significantly different? from those in patients with RA $(p>0 \cdot 1)$. This argues in favour of the importance of the $65 \mathrm{kD}$ myco- $\rightarrow$ bacterial protein in this disease as previousyo suggested from cellular studies in the rat model $\mathrm{af}$ RA. ${ }^{7}$ Further recent data support this concept IgG antibodies to the $65 \mathrm{kD}$ protein from Escherichia coli are not raised in sera from patients with RA (paper in preparation). It is clear, how-० ever, that the mycobacterial proteins used here 0 show high degrees of homology with similar proteins $\overrightarrow{\vec{O}}$ in both prokaryotic and eukaryotic organisms. Thus 3 we cannot at this stage reliably implicate the? mycobacteria as the major immunogens leading to the responses measured here.

The $65 \mathrm{kD}$ and $71 \mathrm{kD}$ mycobacterial proteins have recently been shown to be heat shock/stress proteins. ${ }^{16}$ They show a great degree of homology with human stress proteins, and recent evidence has supported their role in inflammation. ${ }^{17}$ Antibodies to a $90 \mathrm{kD}$ heat shock protein have been shown to be raised in SLE sera. ${ }^{18}$ The human $70 \mathrm{kD}$ protein has $\frac{}{\mathrm{O}}$ been shown to be spontaneously synthesised by chondrocytes in patients with severe osteoarthritis compared with chondrocytes in healthy controls. ${ }^{19} \mathrm{~N}$ In this regard we have shown that IgG and $\operatorname{IgA} \mathrm{N}_{\mathrm{N}}$ antibodies to the human $70 \mathrm{kD}$ protein are also ${ }^{\omega}$ raised in the sera of these same patients with $\mathrm{RA}$ ? (paper in preparation).

In further studies we hope to evaluate the relevance of the specific antibodies to the various stress proteins (especially the $65 \mathrm{kD}$ ) in RA.

This work was supported in part by the MRC. We would like to thank Dr A Rees and Dr J Lamb for helpful discussion. 


\section{References}

1 Cohen I R, Ben-Nun A, Holoshitz J, Maron R, Zerubavel R. Vaccination against autoimmune disease with lines of autoimmune T lymphocytes. Immunol Today 1983; 4: 227-30.

2 Holoshitz J, Matitiau A, Cohen I R. Arthritis induced in rats by cloned $\mathrm{T}$ lymphocytes responsive to mycobacteria but not to collagen type II. J Clin Invest 1984; 73: 211-5.

3 Van Eden W, Holoshitz J, Nevo Z, Frenkel A, Klajman A, Cohen I R. Arthritis induced by a T-lymphocyte clone that responds to Mycobacterium tuberculosis and to cartilage proteoglycans. Proc Natl Acad Sci USA 1985; 82: 5117-20.

4 Cohen I R, Holoshitz J, Van Eden W, Frenkel A. T lymphocyte clones illuminate pathogenesis and affect therapy of experimental arthritis. Arthritis Rheum 1985; 28: 841-5.

5 Holoshitz J, Klajman A, Drucker I, et al. T lymphocytes of rheumatoid arthritis patients show augmented reactivity to a fraction of mycobacteria cross-reactive with cartilage. Lancet 1986; ii: $305-9$.

6 Palacios-Boix A A, Esrada-G I, Colston M J, Panayi G S. HLA-DR4 restricted lymphocyte proliferation to a Mycobacterium tuberculosis extract in rheumatoid arthritis and healthy subjects. J Immunol 1988; 140: 1844-50.

7 Van Eden W, Thole J E R, Van der Zee R, et al. Cloning of the mycobacterial epitope recognized by $T$ lymphocytes in adjuvant arthritis. Nature 1988; 331: 171-3.

8 Ottenhoff T H M, Torres P, Terencio de las Aguas J, et al. Evidence for an HLA-DR4-associated immune-response gene for Mycobacterium tuberculosis: a clue to the pathogenesis of rheumatoid arthritis. Lancet 1986; ii: 310-3.

9 Bahr G M, Sattar M A, Stanford J L, et al. HLA-DR and tuberculin tests in rheumatoid arthritis and tuberculosis. Ann Rheum Dis 1989; 48: 63-8.
10 Bahr G M, Rook G A W, Shahin A, Stanford J L, Sattar M I, Behbehani K. HLA-DR-associated isotype-specific regulation of antibody levels to mycobacteria in rheumatoid arthritis. Clin Exp Immunol 1988; 72: 26-31.

11 Shield M J, Stanford J L, Paul R C, Carswell J W. Multiple skin-testing of tuberculosis patients with a range of new tuberculins, and a comparison with leprosy and $\mathrm{M}$. ulcerans infection. J Hyg (Lond) 1977; 78: 331-48.

12 Thole J R, Keulen W J, Kolk A H J, et al. Characterisation, sequence determination, and immunogenicity of a 64-kilodalton protein of Mycobacterium bovis BCG expressed in Escherichia coli K-12. Infect Immun 1987; 55: 1466-75.

13 Stastny P. Association of the B cell alloantigen DRw4 with rheumatoid arthritis. $N$ Engl J Med 1978; 298: 869-71.

14 Roudier J, Rhodes G, Petersen J, Vaughan J H, Carson D A. The Epstein-Barr virus glycoprotein gp110, a molecular link between HLA DR4, HLA DR1, and rheumatoid arthritis. Scand J Immunol 1988; 27: 367-71.

15 Stastny P, Ball E J, Khan M A, Olsen N J, Pincus T, Gao X. HLA-DR4 and other genetic markers in rheumatoid arthrits. $\mathrm{Br}$ J Rheumatol 1988; 27 (suppl II): 132-8.

16 Lindquist S. The heat-shock response. Ann Rev Biochem 1986; 55: 1151-91.

17 Polla B. A role for heat shock proteins in inflammation? Immunol Today 1988; 9: 134-7.

18 Minota S, Koyasu S, Yahara I, Winfield J. Autoantibodies to the heat-shock protein hsp90 in systemic lupus erythematosus. $J$ Clin Invest 1988; 81: 106-9.

19 Kubo T, Towle C A, Mankin J H, Treadwell B V. Stressinduced proteins in chondrocytes from patients with osteoarthritis. Arthritis Rheum 1985; 28: 1140-5. 